\title{
ОКРЕМІ АСПЕКТИ ЗАСТОСУВАННЯ ЗАПОБІЖНИХ ЗАХОДІВ ЩОДО НЕПОВНОЛІТНІХ: ПОРІВНЯЛЬНИЙ ДОСВІД НІМЕЧЧИНИ ТА УКРАЇНИ
}

\author{
Даниленко А. В. \\ кандидат юридичних наук, \\ доцент кафедри кримінального процесу та організаиії \\ досудового слідства \\ Харківський національний університет внутрішніх справ \\ м. Харків, Україна \\ Кочура О. О. \\ кандидат юридичних наук, доцент, \\ доцент кафедри кримінального процесу, криміналістики \\ та експертології \\ Харківський начіональний університет внутрішніх справ \\ м. Харків, Украӥна
}

Аналізуючи досвід застосування запобіжних заходів щодо неповнолітніх, необхідно відмітити позитивний досвід Німеччини, яка має довгу історію існування системи кримінального правосуддя щодо неповнолітніх. Зокрема, окремі суди, які розглядають справи щодо неповнолітніх існували у Німеччині з 1908 року, але лише після Першої Світової Війни булі введена спеціальна система прав неповнолітніх. Було прийнято два основних закони: закон про втручання щодо неповнолітніх, які перебувають у небезпеці (Jugendwohlfahrtsgesetz 1922 р.), та закон щодо неповнолітніх правопорушників (Jugendgerichtsgesetzc 1923 р.), якими запроваджувалась особлива система кримінального провадження та система санкцій щодо неповнолітніх.

На той час у Німеччині законодавець вперше відкрив можливість застосування виховних заходів щодо неповнолітніх як альтернативу позбавленню волі. Крім того, суворий принцип примусового переслідування неповнолітньої особи був замінений принципом доцільності кримінального переслідування. Таким чином, була отримана можливість не застосовувати кримінального покарання щодо неповнолітніх за скоєння ними нетяжких правопорушень [1]. 
До того ж дані закони змінили вік кримінальної відповідальності з 12 до 14 років, таким чином кримінальне законодавство розповсюджувалось на неповнолітніх осіб з 14 до 18 років.

Хоча, в подальшому, у період часу з 1933 по 1945 рік нацистська система внесла свої корективи у дані положення повторно встановивши можливість кримінальної відповідальності для дітей віком 12 та 13 років.

Закон про захист неповнолітніх 1922 року встановлював дуже широкі можливості втручання держави у життя дітей, таким чином, що держава навіть могла замінювати батьків, які були нездатні виконувати свої освітні обов'язки. Зокрема, встановлювались подібні заходи втручання як: нагляд за свободою, допомога соціальних працівників в покращенні освітнього потенціалу батьків, розміщення у чужій родині чи домі та інші.

Дана система існувала ще протягом тривалого часу і у 1990 році був прийнятий більш прогресивний закон щодо захисту молоді. Відповідно до даного закону органи соціальної та сімейної допомоги повинні діяти як органи допомоги, а репресивні виховні заходи взагалі відмінені.

Таким чином, у Німеччині вже протягом тривалого часу, принаймні з 1990 року, система кримінального правосуддя щодо неповнолітніх діє за принципом мінімального втручання. Даний принцип означає, що кримінальне переслідування щодо неповнолітньої особи буде розпочато і проведено лише у тих випадках, коли це абсолютно необхідно.

Крім того, слід відзначити, що, наприклад, на відміну від Великобританії, де роль профілактики кримінальних правопорушень неповнолітніх виконує поліція, у Німеччині поліція підкорюється суворому принципу законності та зобов'язана повідомляти про всі правопорушення до суду. Це пов'язано із історичними особливостями, коли у нацистський період історії Німеччини поліція дуже часто зловживала владою. Таким чином, поліція не може виконувати жодної профілактичної ролі у роботі з неповнолітнім правопорушниками.

Відповідно до німецького кримінального процесуального законодавства прокурор має право звільнити особу у віці від 14 до 21 року від кримінального переслідування через незначність правопорушення або незначної вини правопорушника. Таким чином, можна виділити такі випадки звільнення неповнолітнього від кримінального переслідування, яке реалізується прокурором:

1) звільнення від кримінального переслідування неповнолітнього у зв'язку із несуттєвістю правопорушення та завданої шкоди; 
2) прокурор може прийняти рішення про звільнення від кримінального переслідування, якщо щодо неповнолітнього застосовані виховні заходи, наприклад, школою чи батьками;

3) неповнолітня особа може бути звільнення від переслідування у випадках, коли прокурор може запропонувати судді у справах неповнолітніх застосувати щодо правопорушника - попередження, заходи по виконанню суспільних робіт, допомога жертві правопорушення, матеріальна компенсація жертві правопорушення, принесення вибачень жертві, праця на благо суспільства чи виплата грошової суми визначеній організації.

Якщо неповнолітня особа виконала всі обов'язки, які на неї були покладені, прокуратура у справах неповнолітніх у співпраці із суддею у справах неповнолітніх може закрити провадження. Частіш 3 все ситуація розгортається таким чином: прокуратура передає обвинувачення до суду, а неповнолітній виконує свої освітні зобов'язання чи звертається до посередника [1].

Кримінальні покарання, що можуть застосовуватись до неповнолітніх судом також підкорюються принципу мінімального втручання. Так, покарання у вигляді позбавлення волі може бути застосовано лише у тих випадках, коли дисциплінарні або виховні заходи неможливі до застосування.

Як і в Україні, покарання у вигляді позбавлення волі неповнолітні у Німеччині відбувають у спеціальних закладах, призначених виключно для неповнолітніх.

Строки позбавлення волі для неповнолітніх у Німеччині складають від 6 місяців до 5 років для осіб від 14 до 17 років. Максимальний строк може бути збільшений до 10 років у випадку скоєння особливо тяжкого злочину, а також у випадку скоєння злочину молодою особою у віці від 18 до 20 років. Позбавлення волі, як найсуворіше покарання застосовується лише тоді, коли виховні заходи не $\epsilon$ ефективними у зв'язку із небезпечністю правопорушення чи з тяжкістю вини[1].

Таким чином, слід відзначити, що можливості застосування примусових заходів виховного характеру замість кримінального покарання з метою найменшого втручання у життя дитини та її подальшого перевиховання $\epsilon$ характерним як для Німеччини, так і для України.

\section{Література:}

1. Frieder Dünkel. Juvenile Criminal Law in Germany: Between Protection and Justice. In Déviance et Société. Volume 26, Issue 3, 2002, pp. 297-313. Source: https://www.cairn-int.info/article-E_DS_263_0297-juvenile-criminal-law-in-germany.htm? contenu=resume. 
2. Code of Criminal Procedure as published on 7 April 1987 (Federal Law Gazette I, p. 1074, 1319), as last amended by Article 3 of the Act of 11 July 2019 (Federal Law Gazette I, p. 1066).

\title{
DOI https://doi.org/10.30525/978-9934-26-179-4-47
}

\section{ЩОДО ПИТАННЯ НЕ ЗАСТОСУВАННЯ ДОКТРИНИ «ПЛОДІВ ОТРУЙНОГО ДЕРЕВА» У КРИМІНАЛЬНОМУ СУДОЧИНСТВІ УКРАЇНИ}

\author{
Заворіна О. П. \\ кандидат юридичних наук, \\ доиент кафедри кримінального процесу та організаиії \\ досудового слідства факультету № 1 \\ Харківський національний університет внутрішніх справ \\ м. Харків, Україна
}

Строк I. A.

кандидат юридичних наук, доиент кафедри кримінального процесу та організаиії досудового слідства факультету № 1

Харківський національний університет внутрішніх справ м. Харків, Украӥна

Нечасва I. O.

викладач кафедри кримінального процесу та організації досудового слідства факультету № 1

Харківський національний університет внутрішніх справ м. Харків, Україна

Доктрина «плодів отруйного дерева» (Fruit of the Poisonous Tree) була сформована у судовій практиці США. Також, доктрина «плодів отруйного дерева» знайшла своє втілення й у практиці ЄСПЛ, зокрема в справах «Gäfgen v. Germany», «Teixeira de Castro v. Portugal», «Шабельник проти України», «Балицький проти України», «Нечипорук і Йонкало проти України», «Яременко проти України» [1]. Нормативною основою цієї доктрини є положення статті 6 Європейської конвенції про захист прав людини і основоположних свобод.

Все частіше суди в Україні почали застосовувати міжнародні доктрини та досвід зарубіжних країн з правознавства в своїй практиці, 